\title{
Rancang Bangun Mobile Commerce di Lamandau Store Berbasis Android berdasarkan User Centered Design (UCD)
}

\author{
Tadonny Vani", Rahmat Hidayat, Arnoldus Yansen Friska Danar Yudhistira \\ Departemen Komputer, Teknologi Rekayasa Komputer, Politeknik Lamandau, Nanga Bulik, Indonesia \\ Email: 1,"tdvnabul@gmail.com, ${ }^{2}$ rahmat.hidayat@gmail.com, ${ }^{3}$ arnoldusdanar@gmail.com \\ Email Penulis Korespondensi: tdvnabul@gmail.com
}

\begin{abstract}
Abstrak-Lamandau Store adalah tempat pemasaran dan penjualan produk-produk hasil pelaku Usaha Mikro Kecil Menengah (UMKM) dan produk Industri Kecil Menengah (IKM) di Kabupaten Lamandau. Sistem pemasaran dan penjualan di Lamandau Store masih secara manual yaitu datang ke toko. Hal ini belum cukup menarik konsumen, sehingga mengakibatkan rendahnya tingkat pemasaran dan penjualan. Penelitian ini bertujuan untuk menghasilkan aplikasi mobile commerce berbasis android yang dapat digunakan untuk menunjang proses pemasaran dan penjualan di Lamandau Store. Penelitian dilakukan dengan beberapa tahapan yaitu Tahap Pengumpulan Data, Tahap Perancangan Sistem dan Tahap Penulisan Laporan. Tahap perancangan sistem dikembangkan berdasarkan metode User Centered Design (UCD). Hasil penelitian menunjukkan bahwa sebuah aplikasi mobile commerce sudah sesuai dengan kebutuhan pengguna dan telah disajikan sebagai inovasi baru di Lamandau Store.
\end{abstract}

Kata Kunci: Lamandau Store; UMKM/IKM; Mobile Commerce; Android; User Centered Design (UCD)

\begin{abstract}
Lamandau Store is a place for marketing and selling products that produced by Micro, Small and Medium Entrepreneurs named Usaha Mikro Kecil Menengah (UMKM) and Small Medium Industry products or Industri Kecil Menengah (IKM) in Lamandau Regency. The marketing and sales system at Lamandau Store has been manual which is costumers come to the store. This has not attracted enough consumers, resulting in lower levels of marketing and sales. This study aims to produce an Android-based mobile commerce application that can be used to support the marketing and sales process at the Lamandau Store. The research was conducted in several stages, namely the Data Collection Stage, the System Design Stage and the Report Writing Stage. The system design stage was developed based on the User Centered Design (UCD) method. The results show that a mobile commerce application is in accordance with user needs and has been presented as a new innovation at the Lamandau Store.
\end{abstract}

Keywords: Lamandau Store; UMKM/IKM; Mobile Commerce; Android; User Centered Design (UCD)

\section{PENDAHULUAN}

Perkembangan teknologi informasi juga telah mengubah pandangan para penggiat teknologi informasi untuk menciptakan terobosan-terobosan dalam bidang bisnis dan promosi untuk meningkatkan daya saing dalam mengembangkan bisnis. Terobosan dalam dunia bisnis, khususnya bisnis jual beli sudah mengarah ke penggunaan telepon genggam. Penggunaan telepon genggam (mobile phone) yang telah berubah fungsi menjadi perangkat multifungsi untuk menjalankan berbagai macam aplikasi mobile, baik itu media untuk mengakses dan mengolah informasi[1]. Penggunaan telepon genggam dalam dunia bisnis jual beli disebut dengan Mobile Commerce dan disingkat $M$-Commerce. Mobile commerce merupakan salah satu bidang yang muncul dari perpaduan antara $E$ commerce dengan teknologi komputasi smartphone[2][3]. Istilah mobile commerce diperkenalkan oleh Kevin Duffey pada tahun 1997 pada saat peluncuran Forum Globa Mobile Commerce. Mobile Commerce adalah pembelian dan penjualan barang atau jasa dan layanan melalui jaringan komunikasi dengan menggunakan perangkat genggam nirkabel[4][5][3]. Mobile commerce memanjakan pelanggan untuk membeli apa saja dengan duduk di mana saja seperti dikantor atau rumah yang penting terkoneksi dengan internet. Mobile commerce sangat mempermudah, mempercepat, dan dapat menjangkau pasar nasional bahkan global dengan biaya yang rendah. Secara umum mobile commerce meliputi mobile, smartphone, dan PDA. Mobile Commerce dapat meningkatkan produktivitas pengolahan data dengan berkecepatan tinggi. Mobile Commerce hemat biaya dan dapat di akses kapan pun dan di mana pun dengan memanfaatkan teknologi informasi dan komunikasi oleh pelanggan ataupun konsumen. Mobile commerce dapat digunakan di mana pun dan kapan pun yang penting memiliki layanan akses internet.

Marketplace merupakan sebuah pasar elektronik (virtual market) di mana pasar tersebut menjadi tempat bertemunya pembeli dan penjual untuk melakukan transaksi[6][7]. Marketplace secara prinsip maupun fungsi sama dengan pasar tradisional, hanya kalau marketplace ini terkomputerisasi dan terkoneksi dengan internet. Marketplace atau pasar elektronik yang mempertemukan penjual dan pembeli yang terhubung melalui transasksi elekronik yang dapat diakases secara cepat, aman, dan dapat dilakukan di mana saja dan kapan saja.

Lamandau Store adalah tempat pemasaran dan penjualan produk-produk hasil pelaku Usaha Mikro Kecil Menengah (UMKM) dan produk Industri Kecil Menengah (IKM) di Kabupaten Lamandau. Kehadiran Lamandau Store ini adalah langkah yang diambil pemerintah daerah Kabupaten Lamandau dalam upaya mewujudkan perhatian pemerintah kepada pelaku UMKM dan IKM dalam hal pemasaran dan penjualan. Sistem pemasaran dan penjualan di Lamandau Store masih secara manual yaitu pembelian harus datang langsung ke Lamandau Store untuk melihat atau menanyakan berbagai macam produk yang tersedia. Sistem ini tentunya menyita waktu konsumen untuk memperoleh informasi dengan mudah dan akurat. Pemasaran dan penjualan produk Lamandau Store belum menggunakan teknologi internet, sehingga kurang dikenal luas. Kurang nya pemasaran dan penjualan 
di Lamandau Store mengakibatkan rendahnya tingkat penjualan dan minat pembeli. Konsumen di luar wilayah Kecamatan Bulit sulit untuk mendapatkan produk-produk hasil pelaku usaha atau industri kecil dan menengah karena pemasaran yang kebanyakan hanya mencapai daerah kota Nanga Bulik.

Atas dasar tersebut diperlukan suatu inovasi dalam proses pemasaran dan penjualan di Lamandau Store. Inovasi tersebut dengan memanfaatkan teknologi mobile, maka dirancanglah sebuah sistem mobile commerce dengan tujuan menghasilkan aplikasi mobile commerce berbasis android yang dapat digunakan untuk menunjang proses pemasaran dan penjualan di Lamandau Store. Mobile phone dipilih sebagai media dalam penelitian ini dengan dasar bahwa mobile phone paling sering digunakan[1][3].

Penelitian pada bidang mobile commerce telah dilakukan oleh beberapa peneliti sebelumnya. Berikut hasil kajian dari penelitian terdahulu yang menunjukkan perbandingan dengan penelitian yang dilakukan saat ini.

a. Betti Dame Hutauruk dkk, mengangkat penelitian dengan judul "Analisis dan Perancangan Aplikasi Marketplace Cindera mata Khas Batak Berbasis Android"[6]. Permasalahan dalam penelitian ini yaitu kurangnya tingkat promosi cindera mata khas batak, sehingga mengakibatkan rendahnya tingkat penjualan dan minat pembeli. Selain itu promosinya terbatas hanya mencapai kota-kota di Sumatera Utara. Dari permasalahan tersebut maka dirancanglah sebuah aplikasi yang dapat membantu pengrajin cindera mata khas batak untuk mempromosikan produk yang dihasilkannya secara luas. Metode pengembangan sistem yang diterapkan adalah model Unified Modeling Language (UML). Hasilnya sebuah aplikasi marketplace berbasis web dan android sudah dibangun untuk menunjang promosi, penjualan dan pembelian cindera mata khas batak[6].

b. Ridoan Saleh Nasution, membahas penelitian dengan judul "Bangun Rumah : Aplikasi Marketplace untuk Penjualan Bahan Bangunan Berbasis Android (Studi Kasus : Toko Bangunan Bali)"[8]. Penjualan bahan bangunan masih secara konvensional, sehingga jangkauan pemasarannya terbatas. Solusi yang diterapkan dalam penelitian ini adalah membangun aplikasi berbasis android. Metode pengembangan sistem yang diterapkan adalah model Waterfall. Hasil penelitian ini yaitu menghasilkan sebuah aplikasi marketplace berbasis android yang dapat meningkatkan jangkauan pasar para pemilik toko[8].

c. Khuluqil Rahmat Hidayat dkk, mengangkat judul penelitian "Perancangan Aplikasi Penjualan Ternak Berbasis Android (Studi Kasus pada Kelompok Ternak Wonosari Pacet Mojokerto)"[9]. Kurangnya informasi yang akurat mengenai harga penjualan dan pemasaran berbagai hasil peternakan, sehingga para tengkulak membeli dengan harga rendah dan menjual kembali dengan harga yang tinggi. Akibatnya pendapatan para peternak rendah. Solusi dari permasalah ini adalah mengembangkan sebuah aplikasi jual beli ternak secara online menggunakan teknologi android. Metode pengembangan sistem yang diterapkan adalah model Software Development Life Cycle (SDLC) Waterfall. Hasilnya adalah sebuah aplikasi penjualan ternak berbasis android sudah dibangun untuk membantu para kelompok ternak menjual produk peternakan secara langsung kepada pembeli dan mendapatkan informasi produk peternakan secara mudah, akurat, dan cepat[9].

d. Muhammad Iqbal dkk, membahas penelitian tentang "Penerapan Metode UCD (User Centered Design) pada Perancangan Aplikasi Darurat Berbasis Android"[10]. Banyak dari masyarakat yang tidak tahu informasi mengenai instansi atau nomor telepon darurat yang harus dihubungi ketika dalam keadaan darurat sehingga mengakibatkan keterlambatan dalam hal pertolongan pertama ketika terjadinya keadaan darurat. Solusinya perancangan aplikasi darurat berbasia android. Metode pengembangan sistem yang diterapkan adalah model waterfall dan User Centered Design (UCD). Hasi penelitian ini mangatakan bahwa sebuah aplikasi darurat sudah di rangcang sesuai dengan kebutuhan pengguna[10].

Penelitian-penelitian terdahulu menunjukkan bahwa penyelesaian permasalahan dalam pemasaran dan penjualan hasil dari produk dengan menerapkan teknologi sebagai solusinya. Permasalahan dalam penelitian ini adalah sistem pemasaran dan penjualan masih secara manual sehingga tingkat penjualan dan minat pembeli rendah. Atas dasar itu diperlukan inovasi baru dalam pemasaran dan penjualan di Lamandau Store. Inovasi ini dapat memanfaatkan teknologi salah satunya teknologi mobile. Metode pengembangan sistem dengan model User Centered Design (UCD) dengan tujuan menghasilkan aplikasi mobile commerce berbasis android yang dapat digunakan untuk menunjang pemasaran dan penjualan di Lamandau Store.

\section{METODOLOGI PENELITIAN}

Gambar 1 memperlihatkan skema metode penelitian yang dilakukan. Bagian ini terbagi dalam tiga tahap utama yaitu : tahap pertama adalah pengumpulan data yaitu semua proses pendukung dalam penelitian ini dikumpulkan ditahap ini, tahap kedua adalah tahap perancangan sistem yaitu proses pembuatan dari sistem yang akan dibangun menggunakan metode pengembangan sistem, tahap terakhir atau ketiga adalah tahap penyelesaian penulisan laporan.

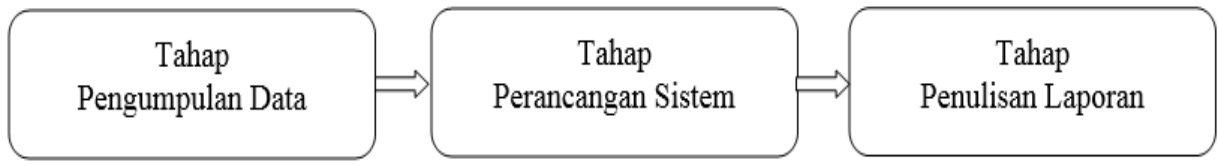

Gambar 1. Skema Metode Penelitian 


\subsection{Tahap Pengumpulan Data}

Tahap pengumpulan data terdiri dari indentifikasi masalah, studi pustaka, dan studi lapangan. Pada tahap pertama dilakukan adalah penetapan permasalahan yaitu pertanyaan yang bersifat umum terhadap permasalahan yang akan diamati. Langkah selanjutnya pada tahap ini yaitu melakukan pencarian dan pengumpulan literatur melalui studi pustaka untuk mendapatkan informasi mengenai apa saja yang berhubungan dengan topik penelitian ini. Bahan dan data yang didapatkan dari studi pustaka tersebut dapat dimanfaatkan untuk mengembangkan penelitian untuk mengatasi permasalahan yang terkait. Studi lapangan dilakukan dengan kombinasi beberapa teknik pengumpulan data yaitu observasi, wawancara, dan kuesioner. Studi lapangan dilakukan untuk mendapatkan informasi mengenai apa saja yang berhubungan dengan topik penelitian ini.

\subsection{Tahap Perancangan Sistem}

Tahap perancangan sistem dilakukan untuk merancang sistem berdasarkan pengumpulan data yang telah dilakukan. Tahap ini menggunakan metode perancangan sistem yaitu User Centered Design (ISO 9241-210:2010). Metode User Centered Design (UCD) adalah proses mengumpulkan umpan balik atau pendapat dari pengguna untuk memperbaiki desain User Interface (UI) yang dibuat[11][12]. Konsep dari UCD adalah pengguna sebagai pusat dari proses pengembangan sistem[10][13][14]. UCD memiliki siklus hidup dalam tahapan desain, sehingga desain yang dibuat menjadi lebih baik[15]. Desain User Interface (UI) yang dibuat berdasarkan dari pengalaman pengguna dan permintaan pengguna. Gambar 2 memperlihatkan proses-proses atau tahapan dalam metode User Centered Design (UCD) menurut ISO 9241-210:2010[11] :

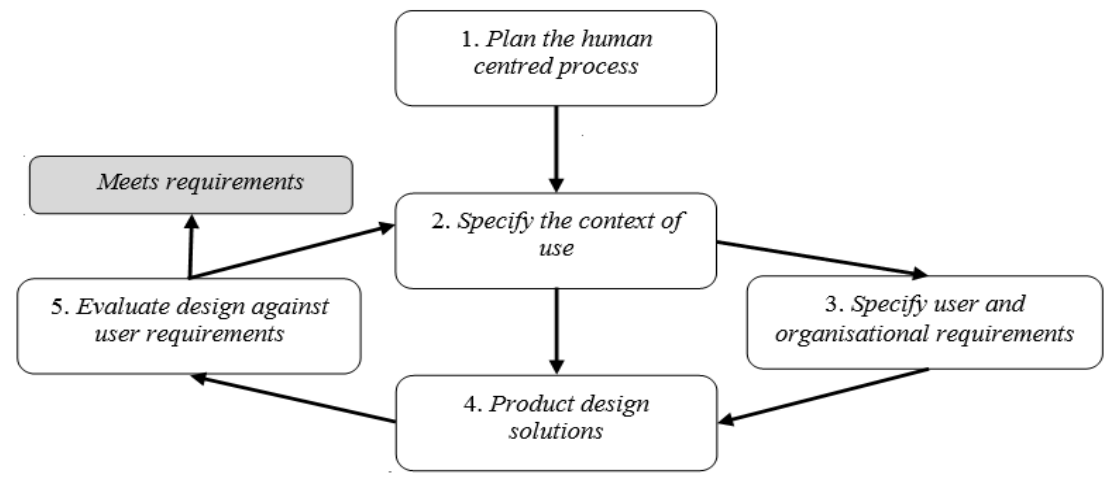

Gambar 2. Tahapan User Centered Design (ISO 9241-210:2010)[11]

1. Plan the human centred process

Tahap ini akan dilakukan analisis data maupun teori yang berkaitan dengan proses membangun sistem yang berpusat kepada pengguna. Analisis data teori, metode yang memiliki tujuan untuk menggali kebutuhan yang diperlukan untuk penelitian ini dan seluruh kebutuhan yang terkait dengan penelitian ini.

2. Specify the context of use (Tentukan Konteks Pengguna)

Tahap ini dilakukan untuk melihat karakteristik dari pengguna. Tahap ini akan menjelaskan untuk apa dan dalam kondisi seperti apa pangguna akan menggunakan produk.

3. Specify user and organisational requirements (Tentukan Persyaratan Pengguna dan Organisasi)

Tahap ini akan mengidentifikasi kebutuhan pengguna dan kebutuhan organisasi terhadap sistem yang akan dibangun.

4. Product design solutions

Tahap ini dilakukan membangun desain sebagai solusi dari masalah yang dianalisis.

5. Evaluate design against user requirements (Evaluasi desain terhadap persyaratan pengguna)

Tahap ini melakukan evaluasi terhadap desain yang telah dilakukan pada tahap sebelumnya. Di mana desain tersebut harus memenuhi persyaratan yang dibutuhkan oleh pengguna. Tahap ini juga digunakan untuk melihat apakah tujuan pengguna dan organisasi telah tercapai.

\subsection{Tahap Penulisan Laporan}

Tahap ini akan dilakukan jika tahapan-tahapan penelitian sebelumnya telah dilakukan. Tahap ini mendokumentasikan proses penelitian yang sudah dilakukan dari tahap awal hingga tahap akhir ke dalam tulisan, yang nantinya akan menjadi laporan hasil penelitian. Gambar 3. menunjukkan proses penelitian yang akan dilakukan.

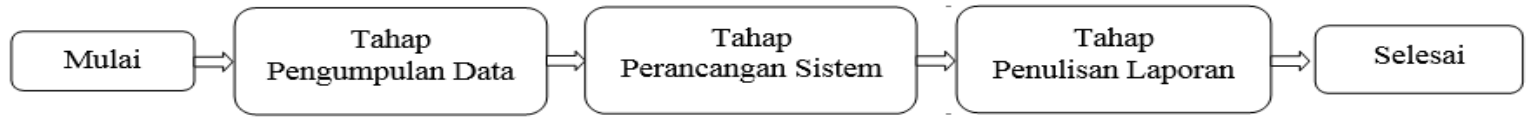

Gambar 3. Proses Penelitian 


\section{HASIL DAN PEMBAHASAN}

\subsection{Tahap Pengumpulan Data}

Pengumpulan data dan informasi dilakukan dengan mempelajari beberapa studi literatur yang didapat dari bukubuku referensi, jurnal, ataupun data-data yang berhubungan dengan objek penelitian sebagai bahan atau dasar pemecahan masalah.

a. Identifikasi masalah

Identifikasi masalah awal adalah kurangnya pemasaran Lamandau Store mengakibatkan rendahnya tingkat penjualan dan minat pembeli.

b. Studi Literatur

Studi literatur dilakukan melalui studi pustaka untuk mendapatkan informasi mengenai apa saja yang berhubungan dengan topik penelitian ini. Bahan dan data studi ini digunakan untuk menjawab dari identifikasi masalah yang ditemukan. Adapun studi literatur yang dilakulan adalah :

c. Studi Lapangan

Studi lapangan dilakukan untuk mendapatkan informasi akurat mengenai apa saja yang berhubungan dengan topik penelitian ini. Studi lapangan dilakukan dengan kombinasi teknik pengumpulan data yaitu Wawancara dan Observasi.

1. Wawancara

Wawancara dilakukan untuk mengetahui permasalahan yang dihadapi dan mengetahui kebutuhan terkait penelitian ini. Wawancara dilakukan kepada 5 orang pengelola Lamandau Store. Hasil wawancara dapat dilihat pada tabel 1 .

Tabel 1 Hasil Wawancara

\begin{tabular}{ll}
\hline \multicolumn{1}{c}{ Pertanyaan } & \multicolumn{1}{c}{ Kondisi Saat Ini } \\
\hline Berapa jumlah UKM yang & Untuk sementara baru 15 \\
tergabung dalam Lamandau & kelompok UMKM/UKM/IKM \\
Store? & yang tergabung dalam \\
& Lamandau Store
\end{tabular}

Bagaimana kondisi penjualan di Lamandau Store saat ini?

Kategori umur yang biasa melakukan pembelian di Lamandau Store?

Proses pemasaran di Lamandau Store untuk saat ini dirasa cukup atau masih kurang?
Kondisi penjualan saat ini cenderung menurun setiap bulannya.

Kondisi saat ini hanya pelanggan yang memerlukan oleh-oleh saja

Untuk pemasaran saat ini masih kurang karena hanya mangandalkan penjualan dari toko Lamandau Store. Selain itu juga pemasaran melalui pameran produk UMKM Kabupaten Lamandau, biasanya hanya dilakukan satu tahun satu kali, jadi kurang menarik pelanggan dari daerah luar kota Nanga Bulik Kabupaten Lamandau.
Mampu membuat
UMKM/UKM/IKM yang ada di
Kabupaten Lamandau
bergabung dan menggunakan marketplace yang dimiliki oleh Lamandau Store
Penjualan di Lamandau Store meningkat dan menguntungkan para UMKM/UKM/IKM di Kabupaten Lamandau.
Pelanggan Lamandau Store meningkat dengan kategori umur $15-60$ tahun keatas. Dapat meningkatkan pemasaran. Membutuhkan sebuah media yang dapat digunakan untuk melakukan pemasaran agar pelanggan dari luar Kota Nanga Bulik bahkan Kabupaten Lamandau dapat mendapatkan informasi produk dari Lamandau Store secar real time yang tidak terbatas oleh jarak dan waktu.

\section{Observasi}

Observasi dilakukan dengan berkunjung ke Toko Lamandau Store sebagai objek penelitian. Proses observasi dilakukan dengan mengamati langsung tentang sistem pemasaran, sistem penjualan serta permasalahan yang dihadapi dilapangan dan melihat kebutuhan Lamandau Store untuk meningkatkan pemasaran

\subsection{Tahap Perancangan}

Pengumpulan data dan informasi dilakukan dengan mempelajari beberapa studi literatur yang didapat dari bukubuku referensi. Hasil tahap pengumpulan data digunakan sebagai data dan informasi dalam tahap perancangan sistem. Perancangan sistem menggunakan metode User Centered Design (ISO 9241-210:2010) yang biasa di 
singkat dengan $U C D[11]$. Metode perancangan User Centered Design (UCD) terdiri dari beberapa tahap berikut [11][16] :

\section{a. Plan The Human Centred Process}

Tahap ini sudah dilakukan seperti yang sudah dijelaskan pada Tahap Pengumpulan Data yaitu kita mentukan identifikasi masalah, melakukan studi literatur yang dibutuhkan untuk memecahkan masalah penelitian, dan melakukan studi lapangan dengan menggunakan dua metode yaitu wawancara dan observasi.

b. Specify The Context of Use (Memahami dan Menentukan Konteks Pengguna)

Memahami dan menentukan konteks pengguna merupakan langkah kedua setelah tahap plan the human centred process dilakukan dalam metode UCD. Tahap ini kita memahami dan menetukan dari pengguna yang akan menggunakan sistem ini.

1) Identifikasi Pengguna

Proses identifikasi pengguna adalah proses mengidentifikasi siapa saja yang akan terlibat secara langsung ataupun tidak langsung dalam menggunakan sistem. Hasil dari identifikasi pengguna adalah :

a. Admin Lamandau Store, yaitu pewakilan dari Lamandau Store yang bertugas untuk mengelola aplikasi Lamandau Store. Admin harus memiliki pengetahuan yang luas terhadap aplikasi Lamandau Store ini.

b. Seller, yaitu pemilik akun yang ada di aplikasi Lamandau Store yang berfungsi untuk mengelola akun yang dimiliki.

c. Buyer, yaitu pelanggan-pelanggan dari aplikasi Lamandau Store yang dapat melakukan transaksi pembelian, bertanya, komplain, dan testimosi produk yang ada di apliaksi Lamandau Store.

d. Pemerintah yang bertindak sebagai pengawas.

2) Karakteristik pengguna

Setelah melakukan identifikas pengguna selanjutnya hasil dari identifikasi pengguna tadi dijabarkan ke dalam Karakteristik pengguna. Karakteristik pengguna seperti pada tabel 2.

Tabel 2. Karakteristik Pengguna

\begin{tabular}{ll}
\hline \multicolumn{1}{c}{ Jenis } & \multicolumn{1}{c}{ Keterangan } \\
\hline Usia & Admin : 20 - 40 Tahun \\
& Seller : 25 - 50 Tahun \\
& Buyer : 15 - 50 Tahuan \\
Pendidikan & Semua jenjang pendidikan \\
Literasi Mobile dan & Admin : Bisa menggunakan komputer dan internet \\
pengalaman & Seller : Bisa menggunakan komputer dan internet \\
& Buyer : Bisa menggunakan mobile dan biasa berbelanja online. \\
\hline
\end{tabular}

c. Specify User and Organisational Requirements (Menentukan Kebutuhan Pengguna dan Organisasi)

Tahap ini merupakan proses ketiga dalam metode $U C D$, di mana tahap ini akan menjelaskan kebutuhankebutuhan sistem yang akan dibangun.

1. Identifikasi Kebutuhan Pengguna

Berdasarkan wawancara dan observasi yang sudah dilakukan kepada responden, maka dapat disimpulkan bahwa kebutuhan pengguna dapat dilihat pada tabel 3 .

Tabel 3. Kebutuhan Pengguna

\begin{tabular}{ll}
\hline \multicolumn{1}{c}{ Jenis Pengguna } & \multicolumn{1}{c}{ Keterangan } \\
\hline Admin & Fungsi manajemen aplikasi secara keseluruhan \\
& Fungsi manajemen aku seller yaitu tambah, edit, dan hapus. \\
& Fungsi laporan penjualan bulanan \\
& Fungsi hapus akun member \\
& Fungsi manajemen komentar \\
& Fungsi manajemen berita \\
& Fungsi manajemen katalok \\
& Fungsi manajemen keranjang belanja \\
& Fungsi customer service penanganan komplai. \\
& Fungsi manajemen penjualan produk \\
& Fungsi pemberitahuan produk \\
& Fungsi pengiriman produk \\
& Fungsi laporan penjualan bulanan \\
& Fungsi manajemen akun member \\
& Fungsi pembelian produk \\
& Fungsi pemberitahuan produk \\
& Fungsi konfirmasi produk \\
Buyer & Fungsi customer service pengajuan komplain. \\
&
\end{tabular}


JURNAL MEDIA INFORMATIKA BUDIDARMA

Volume 5, Nomor 1, Januari 2021, Page 287-296

ISSN 2614-5278 (media cetak), ISSN 2548-8368 (media online)

Available Online at https://ejurnal.stmik-budidarma.ac.id/index.php/mib

DOI 10.30865/mib.v5i1.2544

\section{d. Product Designs Solutions}

Tahap ini adalah tarap perancangan sistem yang didapat dari hasil solusi permasalahan yang dibahas. Dalam tahap ini dilakukan beberapa perancangan yaitu

1. Perancangan proses

Perancangan proses ini digunakan untuk menggambarkan sejumlah proses yang terjadi dalam sistem. Perancangan proses ini terdiri dari :

a) Use case diagram yaitu pemodelan proses berdasarkan perspektif pengguna sistem. Use Case Diagram sistem dapat dilihat pada gambar 4.

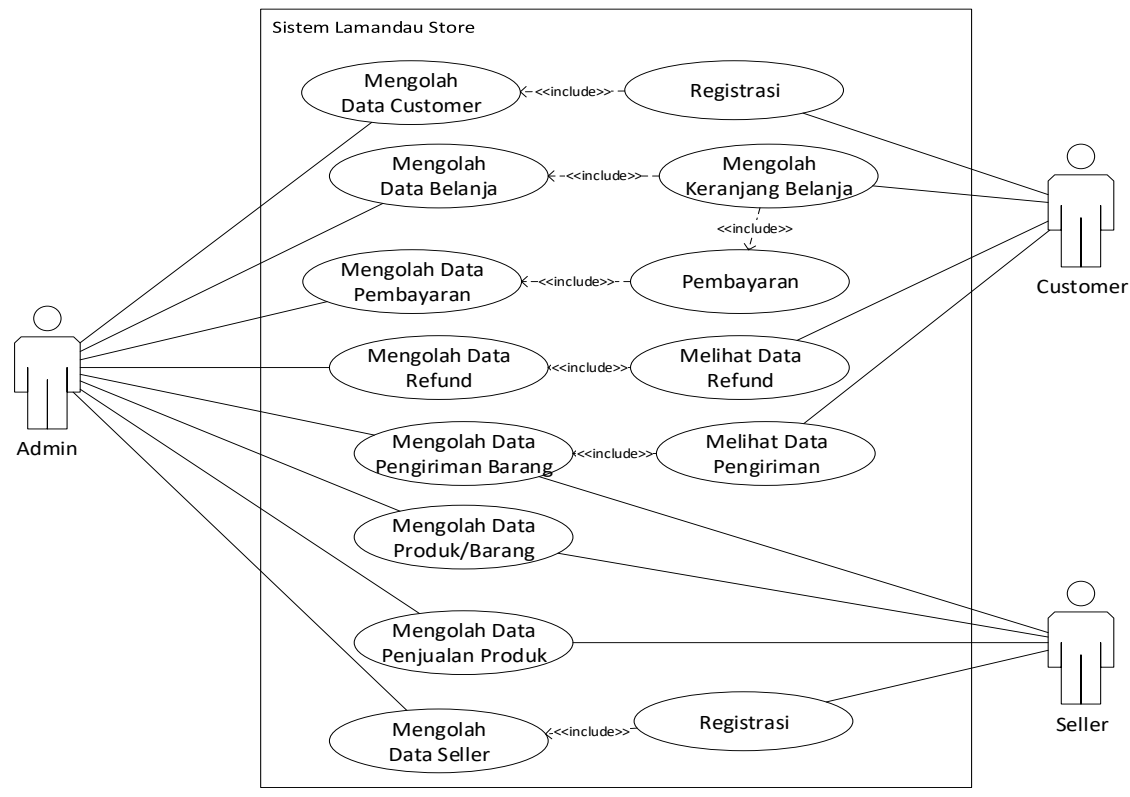

Gambar 4. Use Case Diagram Sistem

b) Activity diagram yaitu pemodelan perilaku pengguna dan objek didalam sistem. Activity diagram proses pendaftaran seller dapat dilihat pada gambar 5.

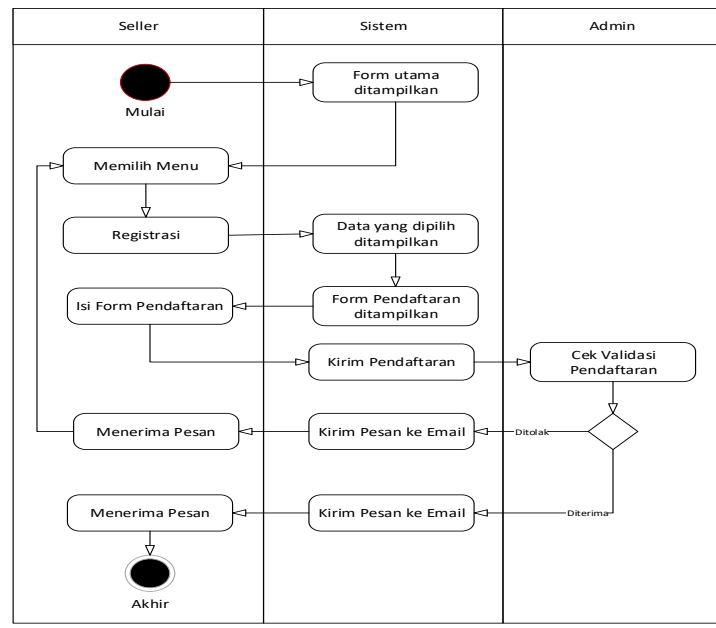

Gambar 5. Activity Diagram Proses Pendaftaran Seller

c) Sequence diagram yaitu menjelaskan urutan proses secara detil yang dilakukan dalam sistem.

2. Perancangan Database

Perancangan database dilakukan untuk menyimpan data yang diperlukan dalam sistem.

3. Perancangan Antarmuka

Perancangan antarmuka adalah perancangan tampilan dari sistem yang akan dibangun. Perancangan antarmuka dilakukan dengan membuat desain sketsa sistem yang akan dirancang terlebih dahulu, setelah itu baru sketsa tersebut divalidasi ke pengguna. Setelah mendapat umpan balik dari pengguna, sketsa yang sudah final akan ditampilkan sebagai acuan dalam pembuatan sistem yang akan dirancang dan dibangun. 
JURNAL MEDIA INFORMATIKA BUDIDARMA

Volume 5, Nomor 1, Januari 2021, Page 287-296

ISSN 2614-5278 (media cetak), ISSN 2548-8368 (media online)

Available Online at https://ejurnal.stmik-budidarma.ac.id/index.php/mib

DOI 10.30865/mib.v5i1.2544

Sketsa tampilan halaman utama merupakan sketsa halaman yang ditampilkan pada saat aplikasi dijalankan. Sketsa awal dari perancangan antarmuka halaman utama yang sudah divalidasi ke pengguna dapat dilihat pada gambar 6.

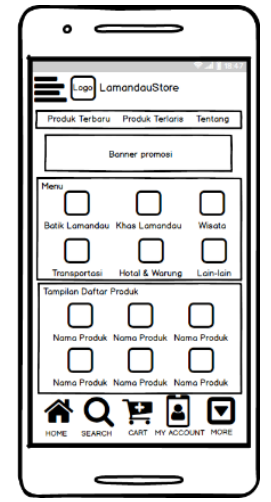

Gambar 6. Sketsa Halaman Utama

Sketsa halaman pilih produk merupakan halaman yang menampilkan produk yang dipilihan. Halaman ini menampilkan gambar, nama, harga, dan jumlah produk. Sketsa halaman pilihan produk dapat dilihat pada gambar 7.

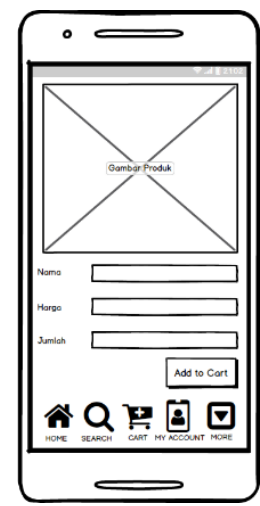

Gambar 7. Sketsa Pilih Produk

Sketsa keranjang belanja merupakan halaman yang berisi produk yang dipilih tanpa harus mengambilnya kembali sebelum membeli. Halaman ini berfungsi untuk menyimpan produk yang diinginkan sebelum melakukan pembelian. Sketsa halaman keranjang belanja dapat dilihat pada gambar 8 .

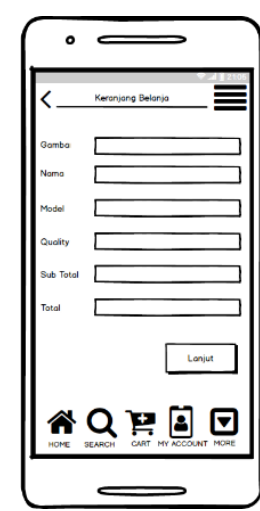

Gambar 8. Sketsa Keranjang Belanja

e. Evaluate Design Against User Requirements

Evaluasi dilakukan terhadap proses pada tahap ke empat yaitu product design solutions dengan tujuan apa yang diinginkan oleh pengguna dan organisasi tercapai.

Gambar 9 menunjukkan hasil evaluasi desain final halaman utama dari sistem yang sudah disetujui oleh pengguna. 
ISSN 2614-5278 (media cetak), ISSN 2548-8368 (media online)

Available Online at https://ejurnal.stmik-budidarma.ac.id/index.php/mib DOI 10.30865/mib.v5i1.2544

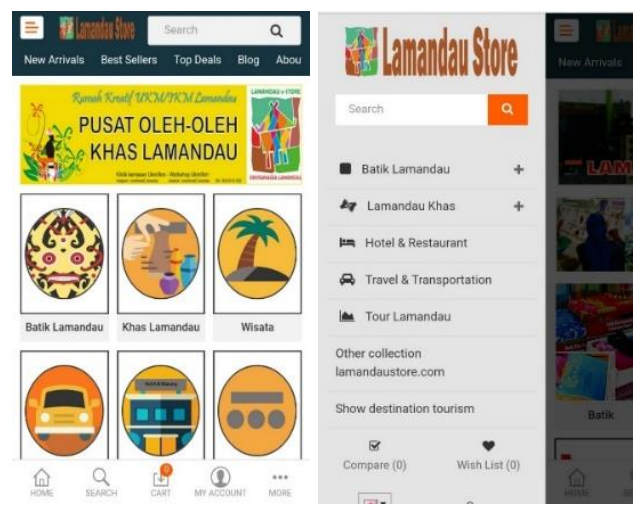

Gambar 8. Tampilan Halaman Utama

Gambar 9 menunjukkan hasil desain final halaman produk yang sudah dievaluasi dan disetujui pengguna.

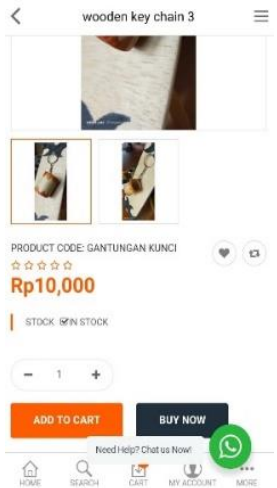

Gambar 9. Tampilan Halaman Produk

Hasil evaluasi desain final keranjang belanja yang sudah mendapat persetujuan dari pengguna dapat dilihat pada gambar 10

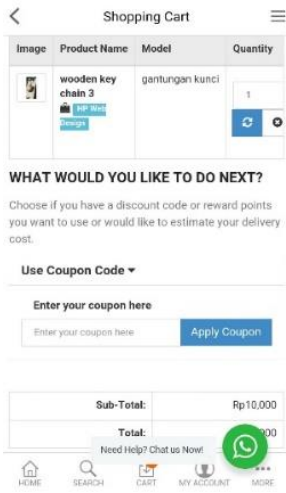

Gambar 10. Tampilan Keranjang Belanja

\subsection{Pengujian Alpha}

Pengujian alpha dilakukan dengan cara menguji tiap-tiap fungsi yang ada pada aplikasi, apakah sudah berjalan dengan baik atau belum. Proses dinyatakan berhasil jika perintah yang dikerjakan pengguna sesuai dengan output yang diharapkan. Halaman utama berjalan dengan baik dan setiap menu dan fungsi yang dipilih dapat berpindah ke halaman yang sesuai. Tabel 4 menunjukkan hasil pengujian alpha.

Tabel 4. Hasil Pengujian Alpha

\begin{tabular}{|c|c|c|}
\hline Deskripsi & Yang diharapkan & Hasil \\
\hline Load halaman utama & Menampilkan halaman utama & Valid \\
\hline Melakukan login admin & $\begin{array}{l}\text { Manampilkan halaman admin jika nama pengguna dan kata kunci } \\
\text { terdaftar dalam database. }\end{array}$ & Valid \\
\hline Melakukan login member & $\begin{array}{l}\text { Menampilkan halaman member jika nama pengguna dan kata kunci } \\
\text { terdaftar dalam database }\end{array}$ & Valid \\
\hline Tombol menu daftar akun & Menampilkan form daftar akun aplikasi & Valid \\
\hline
\end{tabular}


ISSN 2614-5278 (media cetak), ISSN 2548-8368 (media online)

Available Online at https://ejurnal.stmik-budidarma.ac.id/index.php/mib

DOI 10.30865/mib.v5i1.2544

\begin{tabular}{llc}
\hline \multicolumn{1}{c}{ Deskripsi } & \multicolumn{1}{c}{ Yang diharapkan } & Hasil \\
\hline Form daftar akun & Menampilkan form daftar akun dan daftar akun dan dapat melakukan & Valid \\
Tombol login & Menpan dapat daftar akun & Valid \\
Tombol menu & Menampilkan menu-menu yang ada & Valid \\
Gambar Produk & Menampilkan gambar produk & Valid \\
Tombol Pencarian Produk & Menampilkan hasil pencarian & Valid \\
Tambar Daftar Belanja & Mengirimkan dan menampilkan daftar belanjar ke keranjang belanja & Valid \\
Kolom Komentar & Mengirimkan dan menampilkan kolom komentar & Valid \\
Kolom Review & Mengirimkan dan menampilkan kolom review & Valid \\
Kolom Diskusi & Mengirimkan dan menampilkan kolom diskusi & Valid \\
Keranjang Belanja & Menampilkan daftar belanja & Valid \\
Menambah isi keranjang & Menampilkan isi keranjang belanja sesuai produk yang di klik & Valid \\
belanja & tambahkan ke keranjang belanja & \\
Klik nama produk & Menampilkan produk yang dipilih & Valid \\
Halaman kasir & Menampilkan halaman kasir dan transaksi & Valid \\
Rincian Tagihan & Menampilkan Rincian Tagihan & Valid \\
Metode Pembayaran & Menampilkan daftar bank tempat pembayaran & Valid \\
Melakukan pembayaran & Pembayaran akan valid ketika admin menerima uang sesuai dengan id & Valid \\
& transaksi yang ada dimenu transaksi. Lalu member akan konfermasi & \\
Konfirmasi pesanan & pembayaran pada menu profil/akun member & Valid \\
Track order & Mengirimkan dan menampilkan konfermasi pesanan & Valid \\
Pilih Bahasa & Menampilkan track order & Valid \\
Menu Aku & Menampilkan pilihan Bahasa & Valid \\
Tombol Keluar & Menampilkaninformasi akun & Valid \\
\hline
\end{tabular}

\subsection{Pengujian Beta}

Pengujian beta dilakukan dengan cara mencoba aplikasi dan setelah itu pengguna diminta untuk memberikan tanggapannya dengan mengisi kuisioner. Tujuan dari ujicoba beta ini adalah untuk mengetahui tingkat kepuasan pengguna terhadap desain aplikasi. Tingkat kepuasan pengguna diukur dengan menggunakan kuesioner kepuasan yang memiliki atribut estetika dan kesesuaian. Hasil Kuesionar kemudian dihitung dengan rumus Skala Likert. Tabel 5 menunjukkan hasil kuesioner.

Tabel 5. Hasil Kuesioner

\begin{tabular}{|c|c|c|c|c|c|c|}
\hline \multirow[b]{2}{*}{ No. } & \multirow[b]{2}{*}{ Pertanyaan } & \multicolumn{4}{|c|}{ Keterangan Jawaban } & \multirow[b]{2}{*}{ Jumlah } \\
\hline & & $\begin{array}{l}\text { Sangat } \\
\text { Setuju }\end{array}$ & Setuju & Cukup & $\begin{array}{l}\text { Tidak } \\
\text { Setuju }\end{array}$ & \\
\hline 1. & Apakah antarmuka aplikasi ini secara keseluruhan menarik ? & 0 & 10 & 0 & 0 & 10 \\
\hline 2. & $\begin{array}{l}\text { Apakah desain aplikasi ini mewakili kemudahan pengguna } \\
\text { untuk menggunakan dengan baik? }\end{array}$ & 0 & 8 & 2 & 0 & 10 \\
\hline 3. & Menu-menu yang ada sudah lengkap dan mudah dipahami? & 10 & 0 & 0 & 0 & 10 \\
\hline 4. & Apakah tampilan vidual mampu mewakili dengan jelas? & 1 & 9 & 0 & 0 & 10 \\
\hline 5. & $\begin{array}{l}\text { Apakah dapat melakukan pencarian informasi atau } \\
\text { bertransaksi dengan efisien dan mudah? }\end{array}$ & 4 & 6 & 0 & 0 & 10 \\
\hline 6. & $\begin{array}{l}\text { Apakah aplikasi ini memiliki fungsi yang diperlukan oleh } \\
\text { pengguna? }\end{array}$ & 3 & 7 & 0 & 0 & 10 \\
\hline
\end{tabular}

Hasil kuesioner pada tabel 5 dilakukan proses perhitungan dengan menggunakan rumus Skala Likert. Hasil perhitungan pengujian beta dapat dilihat pada Tabel 6 .

Tabel 6. Hasil Perhitungan Pengujian Beta

\begin{tabular}{lccccccc}
\hline \multirow{2}{*}{ Respon } & \multirow{2}{*}{ Nilai } & $\mathbf{7}$ & $\mathbf{2}$ & $\mathbf{3}$ & $\mathbf{4}$ & $\mathbf{5}$ & $\mathbf{6}$ \\
\cline { 3 - 9 } & 4 & 0 & 0 & 10 & 1 & 4 & 3 \\
Sangat setuju & 3 & 10 & 8 & 0 & 9 & 6 & 7 \\
Setuju & 2 & 0 & 2 & 0 & 0 & 0 & 0 \\
Cukup & 1 & 0 & 0 & 0 & 0 & 0 & 0 \\
Tidak setuju & & $\mathbf{3 0}$ & $\mathbf{2 8}$ & $\mathbf{4 0}$ & $\mathbf{3 1}$ & $\mathbf{3 4}$ & $\mathbf{3 3}$ \\
Jumlah Nilai Responden & & 40 & 40 & 40 & 40 & 40 & 40 \\
Nilai Tertinggi & & & & & & &
\end{tabular}


JURNAL MEDIA INFORMATIKA BUDIDARMA

Volume 5, Nomor 1, Januari 2021, Page 287-296

ISSN 2614-5278 (media cetak), ISSN 2548-8368 (media online)

Available Online at https://ejurnal.stmik-budidarma.ac.id/index.php/mib

DOI 10.30865/mib.v5i1.2544

\begin{tabular}{|c|c|c|c|c|c|c|}
\hline \multirow{2}{*}{ Respon } & \multicolumn{6}{|c|}{ Pertanyaan } \\
\hline & 1 & 2 & 3 & 4 & 5 & 6 \\
\hline Nilai Terendah & 10 & 10 & 10 & 10 & 10 & 10 \\
\hline Persentasi Per Soal (100\%) & $75 \%$ & $70 \%$ & $100 \%$ & $\mathbf{7 7 . 5 \%}$ & $85 \%$ & $82.5 \%$ \\
\hline
\end{tabular}

Berdasarkan perhitungan pada tabel 6 dapat disimpulkan bahwa aplikasi mobile commerce berbasis android pada lamandau store dari kepuasan sudah memenuhi tujuan pembuatan aplikasi ini.

\section{KESIMPULAN}

Berdasarkan hasil penelitian yang telah dilakukan dari proses pengumpulan data sampai proses pengembangan sistem menggunakan metode User Centered Design (UCD), sebuah aplikasi mobile commerce telah disajikan sebagai inovasi baru di lamandau store. Hasil pengujian alpha dan beta didapat bahwa aplikasi mobile commerce berbasis android pada lamandau store menunjukkan bahwa antar muka yang dibangun sangat baik dan sesuai dengan kebutuhan pengguna. Aplikasi mobile commerce ini diharapkan dapat menunjang proses pemasaran dan penjualan di lamandau store sesuai dengan tujuan dari penelitian ini. Saran untuk penelitian kedepan adalah mengevaluasi aplikasi untuk kegunaan serta efektivitas agar mendapatkan persepsi serta mengidentifikasi penerimaan pengguna terhadap sistem ini yang nantinya digunakan untuk mengembangkan sistem serta meningkatkan strategi pemasaran maupun penjualan dan mengembangkan perangkat mobile lainnya seperti perangkat IOS dan Windows Phone.

\section{REFERENCES}

[1] T. Vani, M. T. Informatika, P. Pascasarjana, U. Atma, J. Yogyakarta, and M. Konseptual, "Perancangan Model Konseptual untuk Pengembangan Mobile Learning Pengenalan Anatomi Hewan,” vol. 2017, no. Sentika, pp. 17-18, 2017.

[2] A. D. Riyanto and K. Ma'arif, "Aplikasi M-Commerce Berbasis Android Pada Zona Komputer Banjarnegara," Telematika vol. 9, no. 1, pp. 67-77, 2016, doi: 10.35671/telematika.v9i1.415.

[3] U. Akram, A. R. Ansari, G. Fu, and M. Junaid, "Feeling hungry? let's order through mobile! examining the fast food mobile commerce in China," J. Retail. Consum. Serv., vol. 56, no. April, p. 102142, 2020, doi: 10.1016/j.jretconser.2020.102142.

[4] M. Kale, A., Rajivkumar, "M-Commerce : Services and applications M-Commerce : Services and applications," vol. 3, no. 1, pp. 19-21, 2018.

[5] V. Octavianus, "Effect of Mobile E-Commerce Application on Easing Online Transactions," vol. 6, no. 2, pp. 80-84, 2017.

[6] B. R. Betti Dame Hutauruk, Jimmy Febrianus Naibaho, "Analisis dan Perancangan Aplikasi Marketplace Cinderamata khas Batak Berbasis Android,” J. Method., vol. 3, no. 1, pp. 242-246, 2017.

[7] G. Dushnitsky and T. Klueter, "Which industries are served by online marketplaces for technology?," Res. Policy, vol. 46, no. 3, pp. 651-666, 2017, doi: 10.1016/j.respol.2017.01.011.

[8] R. S. Nasution, "Bangun Rumah : Aplikasi Marketplace untuk Penjualan Bahan Bangunan Berbasis Android ( Studi Kasus : Toko Bangunan Bali ) Pendahuluan Studi Literatur," vol. 2, no. 5, pp. 183-191, 2019.

[9] N. S. Hidayat, Khuluqil Rahmat Luki Ardiantoro, "Perancangan Aplikasi Penjualan Ternak Berbasis Android (Studi Kasus Pada Kelompok Ternak Wonosari Pacet Mojokerto),” 2020, doi: 10.1534/g3.120.401131.

[10] M. Iqbal, G. I. Marthasari, and I. Nuryasin, "Penerapan Metode UCD ( User Centered Design ) pada Perancangan Aplikasi Darurat Berbasis Android," vol. 2, no. 2, pp. 201-214, 2020

[11] L. Albani and G. Lombardi (FIMI), "User Centred Design for EASYREACH,” no. November 2010, pp. 1-45, 2010

[12] I. S. Yatana Saputri, M. Fadhli, and I. Surya, "Penerapan Metode UCD (User Centered Design) Pada E-Commerce Putri Intan Shop Berbasis Web," J. Nas. Teknol. dan Sist. Inf., vol. 3, no. 2, pp. 269-278, 2017, doi: 10.25077/teknosi.v3i2.2017.269-278.

[13] E. Retnoningsih and F. N. Khasanah, "User Center Design Knowledge Management System Berbasis Android Pada Usaha Mikro Kecil Menengah ( UMKM ) Kota Bekasi,” vol. 7, no. September, pp. 111-122, 2019.

[14] T. S. Da Silva, A. Martin, F. Maurer, and M. Silveira, "User-centered design and agile methods: A systematic review," Proc. - 2011 Agil. Conf. Agil. 2011, pp. 77-86, 2011, doi: 10.1109/AGILE.2011.24.

[15] S. Wardhana, M. K. Sabariah, V. Effendy, and D. S. Kusumo, "User interface design model for parental control application on mobile smartphone using user centered design method," 2017 5th Int. Conf. Inf. Commun. Technol. ICoIC7 2017, vol. 0, no. c, 2017, doi: 10.1109/ICoICT.2017.8074715.

[16] I. Afrianto and R. G. Guntara, "Implementation of User Centered Design Method in Designing Android-based Journal Reminder Application,” IOP Conf. Ser. Mater. Sci. Eng., vol. 662, no. 2, 2019, doi: 10.1088/1757-899X/662/2/022029. 